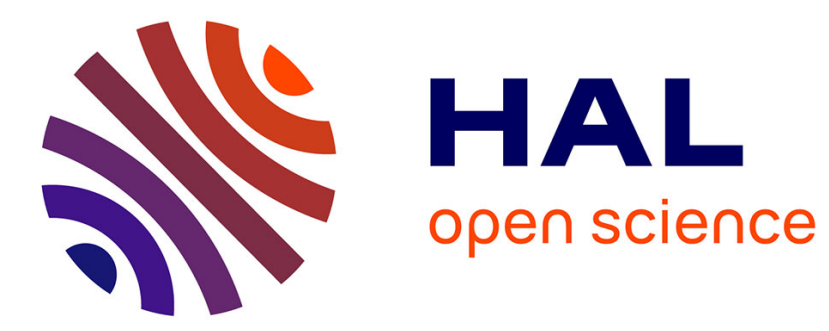

\title{
Upslope-Migrating Bedforms In A Proglacial Sandur Delta: Cyclic Steps From River-Derived Underflows?
}

Pierre Dietrich, Jean-François Ghienne, Alexandre Normandeau, Patrick Lajeunesse

\section{- To cite this version:}

Pierre Dietrich, Jean-François Ghienne, Alexandre Normandeau, Patrick Lajeunesse. UpslopeMigrating Bedforms In A Proglacial Sandur Delta: Cyclic Steps From River-Derived Underflows?. Journal of Sedimentary Research, 2016, 86 (2), pp.113-123. 10.2110/jsr.2016.4 hal-02067992

\section{HAL Id: hal-02067992 https://hal.science/hal-02067992}

Submitted on 14 Mar 2019

HAL is a multi-disciplinary open access archive for the deposit and dissemination of scientific research documents, whether they are published or not. The documents may come from teaching and research institutions in France or abroad, or from public or private research centers.
L'archive ouverte pluridisciplinaire HAL, est destinée au dépôt et à la diffusion de documents scientifiques de niveau recherche, publiés ou non, émanant des établissements d'enseignement et de recherche français ou étrangers, des laboratoires publics ou privés. 


\section{Sedimentary}

\section{Research}

Journal of Sedimentary Research, 2016, v. 86, 113-123

Current Ripples

DOI: http://dx.doi.org/10.2110/jsr.2016.4

\title{
UPSLOPE-MIGRATING BEDFORMS IN A PROGLACIAL SANDUR DELTA: CYCLIC STEPS FROM RIVER-DERIVED UNDERFLOWS?
}

\author{
PIERRE DIETRICH, ${ }^{1}$ JEAN-FRANÇOIS GHIENNE, ${ }_{1}^{1}$ ALEXANDRE NORMANDEAU,, 3 AND PATRICK LAJEUNESSE, ${ }^{2}$ \\ ${ }^{1}$ Institut de Physique du Globe de Strasbourg, UMR 7516 CNRS/Université de Strasbourg, 1 rue Blessig, 67084 Strasbourg, France \\ ${ }^{2}$ Centre d'Étude Nordiques and Département de Géographie, Université Laval, Pavillon Abitibi-Price, 2405 Rue de la Terrasse, Québec, Québec GIV 0A6, Canada \\ ${ }^{3}$ Department of Geography, Queen's University, Kingston, Ontario K7L 3N6, Canada \\ e-mail:pdietrich@unistra.fr
}

\begin{abstract}
Backstepping cross-strata on steep foresets of a Gilbert-type proglacial fluviodeltaic system are ascribed to cyclic steps and other associated supercritical bedforms. They provide insight into how sandur river flows transition into the marine realm. These sedimentary structures are located on steep foresets (up to $17^{\circ}$ ) with corresponding top-lying, flat-based topsets in an upper Pleistocene delta on the North Shore of the Gulf of St. Lawrence, Québec, Canada. Packages of backstepping cross strata of sand and gravel, lying in the lower part of the delta front outcrop, are organized in 10-20 m spaced pseudo-foresets with a mean slope of $11-12^{\circ}$ seawards. Backstepping strata include frequent internal erosion surfaces that onlap upslope on pseudo-foresets and are interpreted as cyclic steps. Narrow, deep, and asymmetrical scours and upslope-climbing cross beds are interpreted as chutes-and-pools and antidunes respectively. Very shallow $(<15 \mathrm{~m})$ depositional paleo-bathymetry is inferred from the preservation of the delta brink. The well-organized stratal pattern in cyclic step to antidune deposits indicates relatively steady and uniform flow patterns. There is insufficient distance for a headscarp large enough to transform to the volume of observed accreted sands or for a flow transformation from a gravitational collapse to net-depositional cyclic steps. These deposits are sandier than the topsets beds and are thus not derived from them, but rather correspond to topset erosional surfaces. The development of cyclic steps from hyperpycnal flows was likely enhanced by tidal drawdown processes. The resulting sediment-laden supercritical flows plunged inertially and evolved into an underflow that generated the cyclic steps on the upper foresets. The cyclic steps have a high aspect ratio and represent an end member of coarse-grained sediment deposited on steep slopes, in contrast to low-gradient, low-aspect-ratio muddy deposits.
\end{abstract}

\section{INTRODUCTION}

Bedforms and resulting cross-strata originating from supercritical flow conditions have been identified from subaerial and subaqueous outwash systems (Russell and Arnott 2003; Duller et al. 2008; Lang and Winsemann 2013; Girard et al. 2015) to the deep sea (Cartigny et al. 2011; Talling 2014), including deltaic (Massari 1996; Hughes Clarke et al. 2012) and fluvial (Fielding 2006) systems. Recently, their significance and origin has been better understood owing to the higher resolution of geophysical imaging tools, in situ monitoring, and numerical or analogic models (Mulder and Alexander 2001; Sequeiros et al. 2009; Spinewine et al. 2009; Muto et al. 2012; Cartigny et al. 2014; Covault et al. 2014). Among structures related to supercritical flow conditions, those referred to as cyclic steps (Parker 1996) have received increasing attention during the last decade (e.g., Spinewine et al. 2009; Kostic et al. 2010; Cartigny et al. 2013; Postma et al. 2014). Large-scale ( $>$ hundreds of $\mathrm{m}$ ) finegrained (fine sand and silt) up-slope migrating sediment waves, interpreted or not as cyclic steps, are ubiquitous in deep-water channels and levees (Hughes Clarke et al. 1990; Migeon et al. 2000; Fildani et al. 2006; Lamb et al. 2008; Zhong et al. 2015). Smaller examples, described as crescentic bedforms, have been identified over delta slopes (Hill 2012; Hughes Clarke et al. 2012; Turmel et al. 2015) and in the axis of deep-water (Smith et al. 2005; Babonneau et al. 2013; Paull et al. 2013) and shallow-water (Hughes Clarke et al. 2012; 2014; Normandeau et al. 2014; 2015) submarine canyons. Coarse-grained cyclic steps (sand and gravel) have been so far less well documented (Postma et al. 2014; Postma and Cartigny 2014; Ventra et al. 2015; Girard et al. 2015)

Although the identification of supercritical bedforms is crucial for the reconstruction of past depositional environments and in the understanding of formative flow dynamics, there is no full consensus on their genesis (e.g., Lee et al 2007; Paull et al. 2010). The most commonly accepted view of their origin relate to turbidity currents associated with mass-wasting processes (Piper et al 2002; Lamb et al. 2008; Talling 2014). In places where delta foresets accrete under tidally-influenced conditions, tide-supported gravity flows may occur (Wright and Friedrichs 2006; Ayranci et al. 2012). The potential link with river-derived hyperpycnal flows is less explored (Turmel et al. 2010; Ventra et al. 2015) but has been suggested to explain some particular occurrence of such features in fan-delta settings fed by bedload-dominated rivers (Prior and Bornhold 1989, 1990; Babonneau et al. 2013; Turmel et al. 2015). A better understanding of these structures requires the identification of the full spectrum of their occurrence in the variety of depositional settings.

Here, we illustrate a case study where supercritical flow conditions can be inferred from coarse-grained, undulating backstepping cross-strata associated with subordinate backsets. Such structures, which arguably resulted from upslope-migrating cyclic steps, characterize a fluvioglacial delta succession where there is no evidence for the occurrence of related mass-wasting processes. These structures typify channelized shallow $(<20 \mathrm{~m})$ environments in the upper part of the deltaic foresets, immediately beneath the foreset-topset 


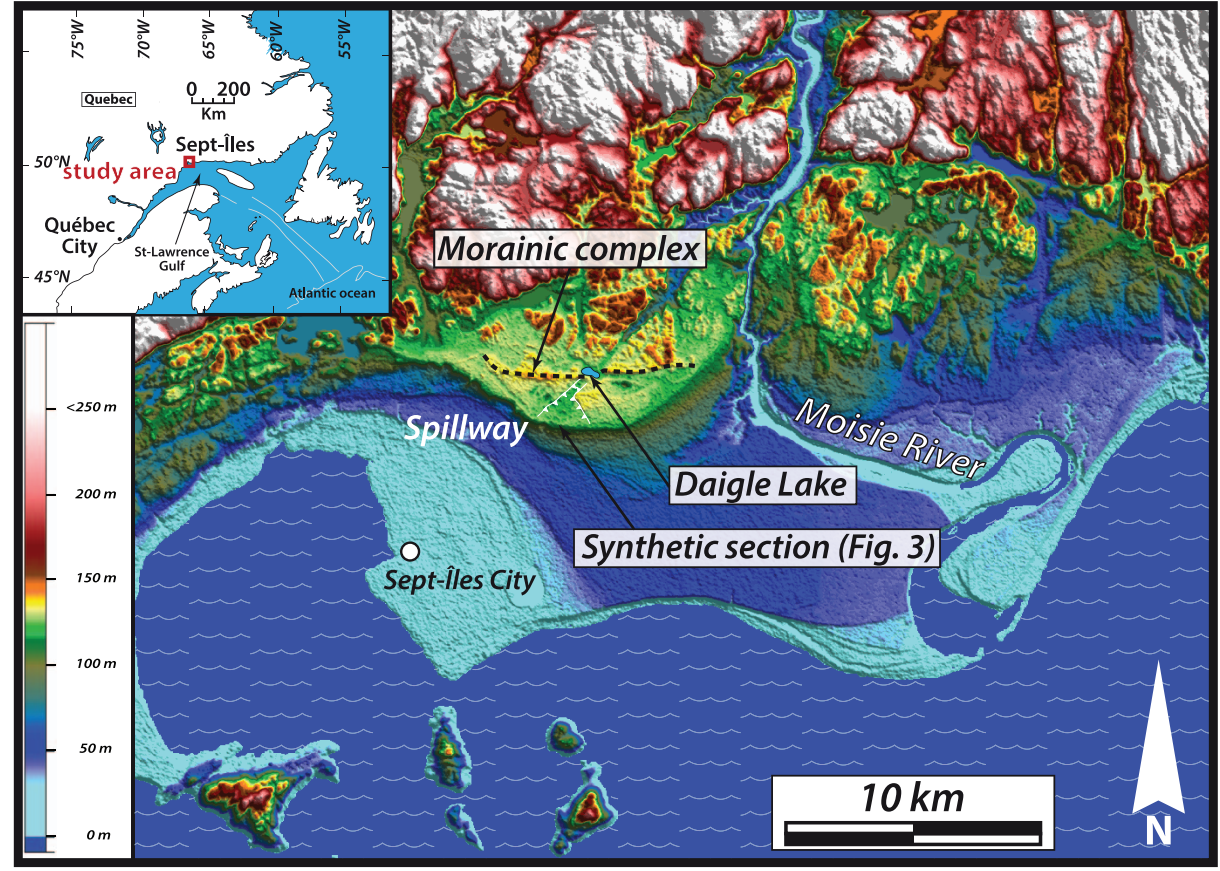

FIg. 1.- The Sept-Îles area on the North Shore of the Gulf of St. Lawrence, Quebec. Backstepping cross-strata were observed along foresets of a Gilbert delta exposed in a sand pit at the southern edge of a large, topographically well expressed subaqueous outwash fan. The red bar locates the synthetic profile of Figure 3. contact. This contribution thus sheds new light on the potential link between cyclic-step-related bedforms and hyperpycnal underflows.

\section{GEOLOGICAL SETTING}

The study area is located on the north shore of the Gulf of St. Lawrence (Québec, Canada) $10 \mathrm{~km}$ north of the city of Sept-Îles (Fig. 1). We describe a suite of sedimentary structures and facies, among them the backstepping cross-strata ascribed as being cyclic steps, characterizing a Gilbert-type fluvioglacial fan delta (Fig. 2). This delta constitutes the downstream reach of a triangle-shaped spillway exiting a morainic ridge emplaced $3 \mathrm{~km}$ upstream (The Daigle Lake Morainic Complex, Fig.1).

Lying at $135 \mathrm{~m}$ above sea level (the marine limit of the literature, Dredge 1983), this Gilbert delta marks the first emergence of the sedimentary system following the retreat of the Laurentide Ice Sheet margin and the deglaciation of the area ca. $12 \mathrm{ka}$ cal BP. The deglaciation was initially marked by a succession of stillstands, the morainic ridge being the last (Shaw et al. 2002; Occhietti et al. 2011; Lajeunesse and St-Onge 2013). The study area exclusively experienced a glacio-isostatically forced regression since the emergence of the system. Despite high rates of sea-level fall (several $\mathrm{cm} / \mathrm{yr}$, Shaw et al. 2002; Peltier et al. 2015), no RSL fluctuations can be evidenced from the stratigraphic architecture. It suggests that the development of the proglacial delta formed in a short timespan: tens to a few hundreds of years considering other comparable case studies on fjord-head or sandur deltas that typically have progradation rates in the $10-50 \mathrm{~m} . \mathrm{yr}^{-1}$ range (e.g., Syvitski and Farrow 1983; Lønne and Nemec 2004; Gilbert and Crookshanks 2009).

Observations were carried out in a pit excavation located at the edge of the sandur plain (Fig. 1). Faces up to $25 \mathrm{~m}$ high, however with poor lateral continuity, were available either perpendicular or parallel to the foreset bedding. Figure 3 is a synoptic compilation of the observed architectural elements.

\section{BACKSTEPPING CROSS-STRATA IN A DELTA-FRONT DEPOSITIONAL SETTING}

The delta architecture shows three superimposed depositional units, from the base to the top (Figs. 2, 3): (i) upper delta foresets, bearing the backstepping cross-strata; (ii) distal sandur to mouth deposits constituting the topsets; (iii) beach barrier and storm-berm deposits. The stratigraphic emplacement of the backstepping cross-strata is detailed below; their description occurs in a further section.

\section{Description of Depositional Units}

Two facies assemblages are observed in the upper delta foresets. They consist of either fine- to medium-grained sand, including silty intervals, or of coarse-grained pebbly sand. The former are gently sloped $\left(10^{\circ}\right)$ and regularly stratified; the latter, which include the backstepping packages, are more intriguingly organized. The two facies assemblages occur in turn repeatedly. In both cases, master beds dip to the SW.

Fine- to medium-grained sand shows gently dipping, well-stratified beds, 5-30 cm thick. Some of the foreset beds include a well-defined break in slope. Upslope, a concave-up profile is observed in places (Fig. 3). Sand beds occasionally show finer-grained bioturbated drapes (Fig. 4A). In-phase climbing ripples, cross lamination, and foreset-parallel planar laminae prevail. Millimeter-thick horizons concentrating heavy minerals are observed in places.

The coarse-grained facies assemblage shows a variety of architectures (Figs. 2, 3, 4B): steep (up to $27^{\circ}$ ) foresets including fining-upward sequences, channel structures and related backstepping cross-strata and V-shaped scours. Steep foresets are regularly organized with bed-parallel lamination. Suites of steep foresets are in some cases truncated and unconformably overlain by finer-grained and gentler-dipping foresets (Figs. 3, 4B). A view perpendicular to the foreset slope revealed that the coarse-grained assemblage including the backstepping cross-strata specifically constitute the infill of channelized structures (Fig. 3, left). The channel form was up to $10 \mathrm{~m}$ deep and less than $20 \mathrm{~m}$ wide, and characterized by steep $\left(>60^{\circ}\right)$ margins. Finally, numerous V-shaped, steep-flanked $\left(45^{\circ}\right)$ and meter-scale scours also occur in the coarse-grained pebbly sand (Figs. 2, 4B). Their infill is massive to faintly stratified. The $\mathrm{V}$-shaped scours include upslope-dipping (up to $17^{\circ}$ ) backsets that fine upward from clast-supported pebbles and cobbles to sand. Backsets occasionally show a cyclic organization marked by repeated change in grain size (Fig. 4B).

The topset beds, $\sim 6 \mathrm{~m}$ thick, constitute an erosion-based fining-upward unit. Topset beds wedge out southward beneath the erosion-based third unit (Figs. $2,3)$. The overall bedding is essentially horizontal. The lower bounding surface shows in places superimposed channelized structures, up to $2.5 \mathrm{~m}$ deep and in excess of $15 \mathrm{~m}$ wide, cutting into foreset deposits. However, a basal transitional 


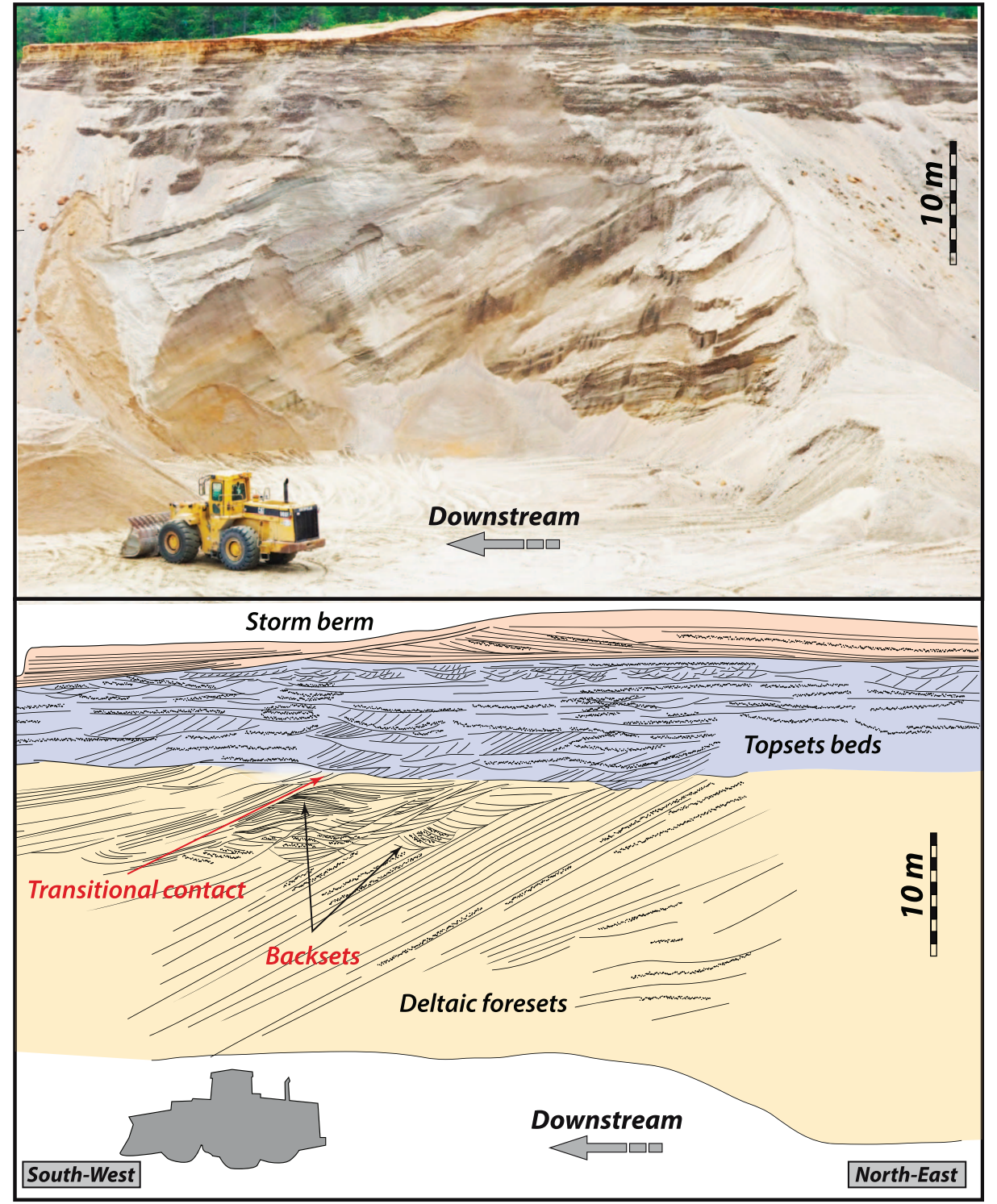

FIG. 2.-Depositional units in Gilbert-type delta. Note that delta foresets display both steep-sloped beds with backsets and fine-grained, gentler-sloped beds (to the left). Foresets are overlain by topsets, with either a transitional (red arrow) or sharp contact. The flat-based upper unit (storm berm) shows landward-dipping (toward the right) master beds. contact is in places evidenced laterally (Fig. 2). Planar, trough, and sigmoidal cross-stratified pebbly sand prevails. Clast-supported, frequently imbricated, well-rounded gravels include subordinate ball-shaped clasts. Uniform paleocurrents toward the SW are evidenced by laminae dips and pebble imbrication.
The third unit is located on the outer edge of the topsets. It forms a subdued flat-topped ridge, reaching up to $2.5 \mathrm{~m}$ high. Its cross section is asymmetrical. Seaward, a sloped $\left(5^{\circ}\right)$, concave-up erosional surface is observed (Figs. 2, 3). Landward, a more extensive, gently dipping $\left(\right.$ ca. $\left.1^{\circ}\right)$, planar surface develops over a distance of $150 \mathrm{~m}$. Internally, sloped master beds (ca. $4^{\circ}$ ) evidencing a

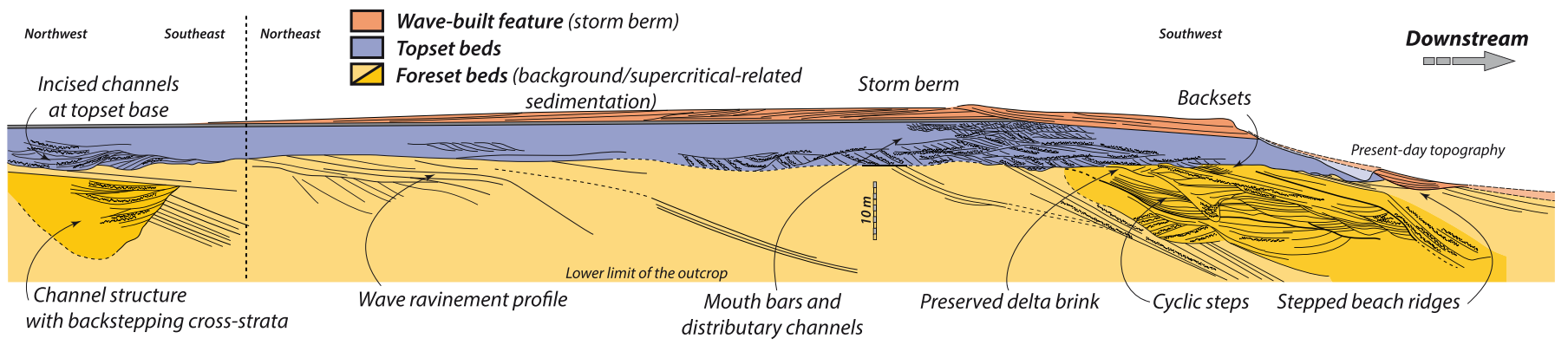

FIG. 3.-Synoptic profile of the Sept-Îles Gilbert-type, proglacial, deltaic system. Backstepping cross-strata are identified as channel fills (deep yellow) embedded within the foreset beds. Paleoflow is to the right. 

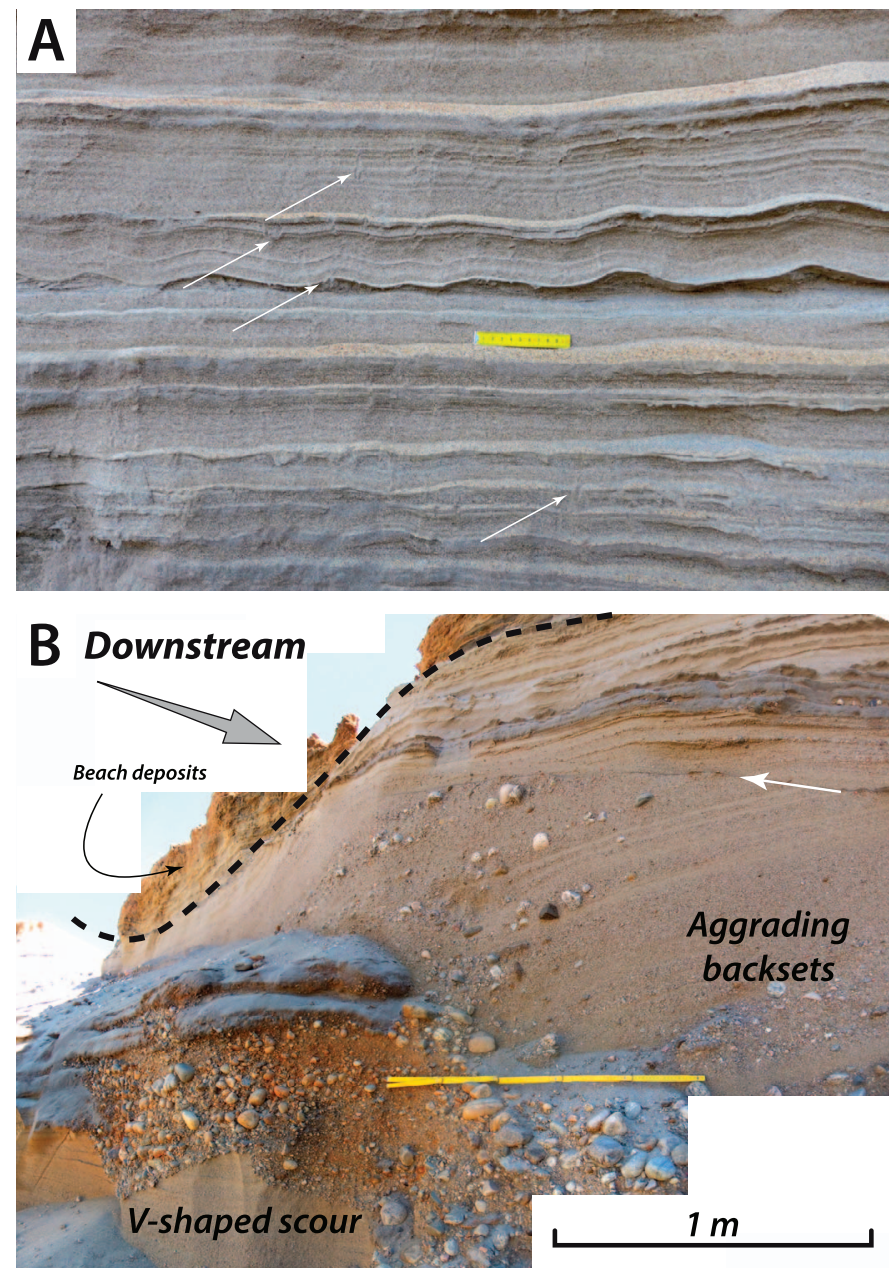

FIG. 4.-A) Fine-grained rippled sand and silt drapes with abundant bioturbation (white arrows) tied to background sedimentation stages. The yellow scale is $10 \mathrm{~cm}$ long. B) V-shaped scour with backsets sharply truncated (white arrow) by fine-grained foresets. Note alternating coarse and fine facies constituting the backsets. Regressive beach deposits are at the top of the succession. The yellow rule is 1 meter long.

landward progradation have downlap relationships over the basal contact (Figs. 2, 3). Pebbles to pebbly coarse sand with bed-parallel laminae, occasional pebble imbrication, and smaller-scale planar cross-strata prevail. Both indicate north- to northwestward-oriented currents. Beds of open-framework gravels characterize the upper part of the succession. Landward, the third unit thins progressively, down to less than one meter in thickness. At the base, a distinctive finely laminated mud bed, $10-30 \mathrm{~cm}$ thick, includes organic debris and rare pebble-size lonestones.

\section{Detailed Description of Backstepping Cross-Strata}

Backstepping cross-strata were observable on a single continuous vertical face, $12 \mathrm{~m}$ high and $70 \mathrm{~m}$ long, which intersected the deltaic upper foreset deposits (Fig. 5). It was however poorly accessible due to slope instabilities.

At the foreset scale, an undulating bedding with $11-12^{\circ}$ mean dips is observed. Internal erosion surfaces form either deep and narrow scours or steep-sloped amalgamation surfaces, in the middle and lower part of the exposure, respectively. Amalgamation surfaces, here referred to as "pseudo-foresets," correspond to seaward-oriented, concave-up truncation surfaces (Fig. $6 \mathrm{~A})$. They have a $10-20 \mathrm{~m}$ spacing and dip at higher angle $\left(<25^{\circ}\right)$ than the overall mean foreset slope. Deposits observed in the lower, middle, and upper parts show distinctive bedding patterns.
The lower part of the section exposes the backstepping cross-strata (Fig. 5). It consists of sand or pebbly sand including rare drapes of fine sand. Individual strata are conformably superimposed or bounded by low-angle subordinate erosional surfaces. They successively onlap landward onto pseudo-foresets. They have a hummocky pattern including some second-order, convex-up bed surfaces (Fig. 6B) and are truncated seaward by the seaward-next pseudo-foreset. Internal mean dip of the strata in between two successive pseudo-foresets is either horizontal or seaward dipping. Only strata related to convex-up geometry have weak landward dips. At the sub-bedform scale, laminated to diffusely layered sand prevails. Faintly to well-laminated sand especially characterizes convex-up geometries. Normal grading occurs in a few massive sand beds. Gravels, floating into a laminated to diffusely layered sand matrix, are concentrated in beds abutting against the pseudo-foresets. More abundant gravels in the lower part of the succession, which also contains some decimeter-scale sand intraclasts (Fig. 5), provide evidence for an overall fining-upward trend. Liquefaction structures are present. Small-scale flame structures in fine-grained intervals are affected by a conspicuous top-to-the-south shear deformation (Fig. 6C). Convolute bedding is also present.

A narrow, deep, and asymmetrical scour and its infill were observed in the middle of the exposure (Fig. 5). Downstepping extensional fractures affecting both the infilling and the underlying truncated sands are observed on its landward flank. Massive and chaotic to faintly laminated pebbles grade upward into pebbly sand with undulating beds and diffuse laminae, which are similar in nature to those of the lower part of the exposure. They form distinctive upslopedipping backsets onlapping the landward flank and essentially conformably overlying the opposite, seaward flank of the scour (Fig. 5).

In the upper part of the exposure, above a sharp truncation surface, stratified sands are better organized (Figs. 5, 6D). They show regular seaward-dipping, 25-40 cm thick, master beds including tangential climbing cross-strata with upslope dips, ca. $1 \mathrm{~m}$ in wavelength (Fig. 6D). They consist of laminated granular sands with scattered gravels.

\section{INTERPRETATIONS}

\section{Depositional Architecture and Constraints on Paleo-Water Depths}

The flat-topped ridge comprising the third, topmost unit is interpreted as a wave-built feature. Planar cross-strata and northward-dipping master beds are washover deposits (Orford et al. 1991). The latter constitute a typical storm berm, similar to those observed in sandur settings (Hine and Boothroyd 1978). The steep seaward-dipping erosional surface corresponds to the beachface of the highest-stage beach ridges. The clastics prograded landward into a finer-grained back-barrier showing laminated muds deposited in slackwater conditions at the distal toe of the sandur (Hine and Boothroyd 1978). Lonestones are interpreted as ice-rafted debris. The horizontal, landward development of the washover complex over the topset beds conforms to the idea of rapid construction and abandonment of the entire system in a short timespan. The glacio-isostatic uplift did not prevent the retrograding behavior of the barrier.

The stratigraphic contact between the storm berm and the underlying topsets approximates the mean high tide at the time of the delta progradation. The lower bounding surface of the topsets was formed close to the mean low tide, considering a present-day tidal range of ca. $3.5 \mathrm{~m}$. The occasional preservation of transitional contacts between topset and foreset beds shows in addition that the correlative delta brink was positioned at the same level (Figs. 2, 3). Thus, the position of the topset-foreset contact mostly reflects a regular erosion depth by mouth channels. In this view, cross-stratified pebbly sands of the topsets correspond to the infill of constantly shifting channels within the intertidal toe of a prograding sandur (Syvitski and Farrow 1983). The deepest of these channels (Fig. 3) highlights particularly severe downcutting related to springtide episodes (Smith et al. 1990) and/or to flood conditions on the delta plain. Planar and trough cross-strata essentially record normal flow conditions. Sigmoidal cross-strata may specifically relate to high rates of sedimentary aggradation at flow transitions between dunes and upper-stage plane beds 


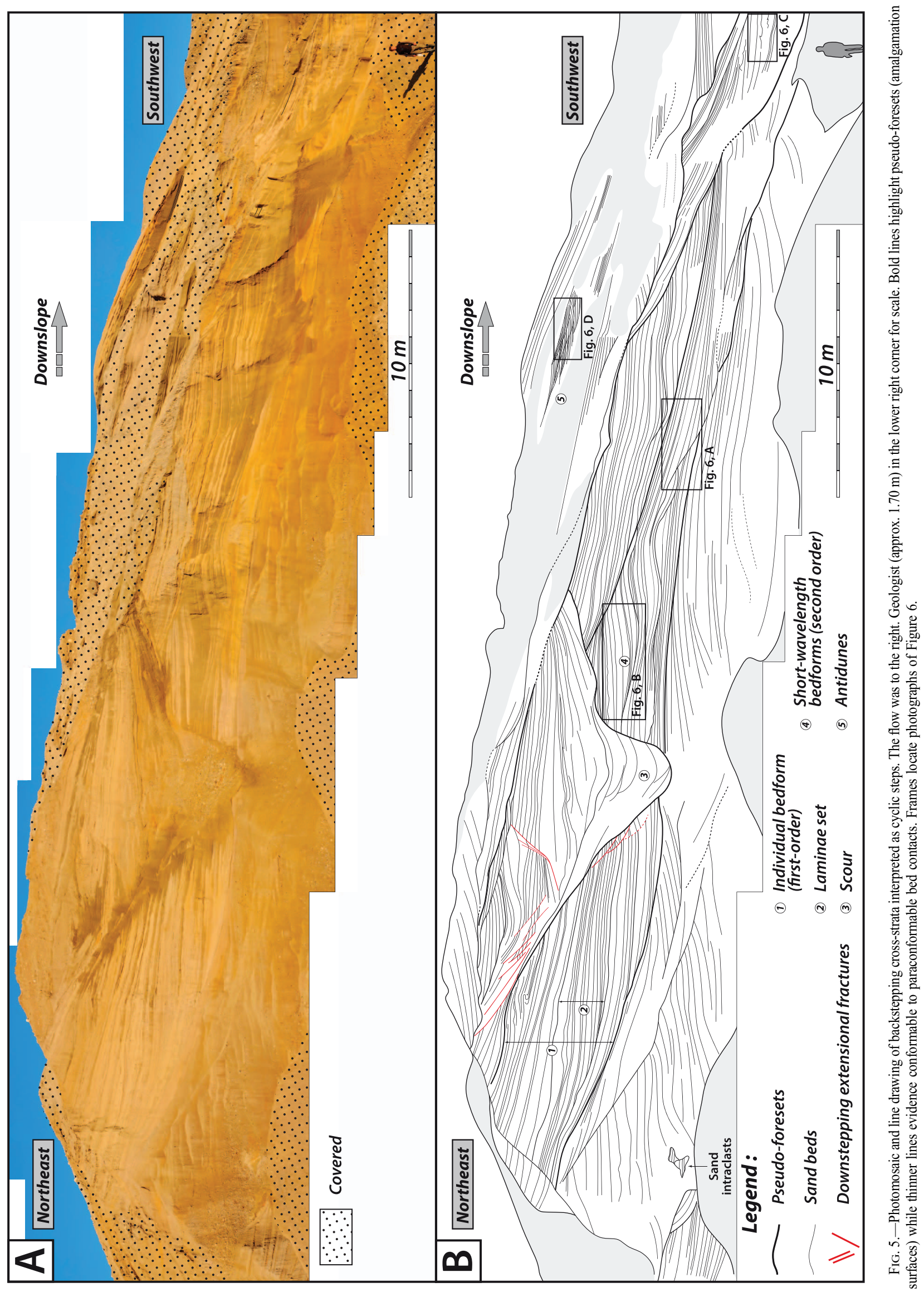



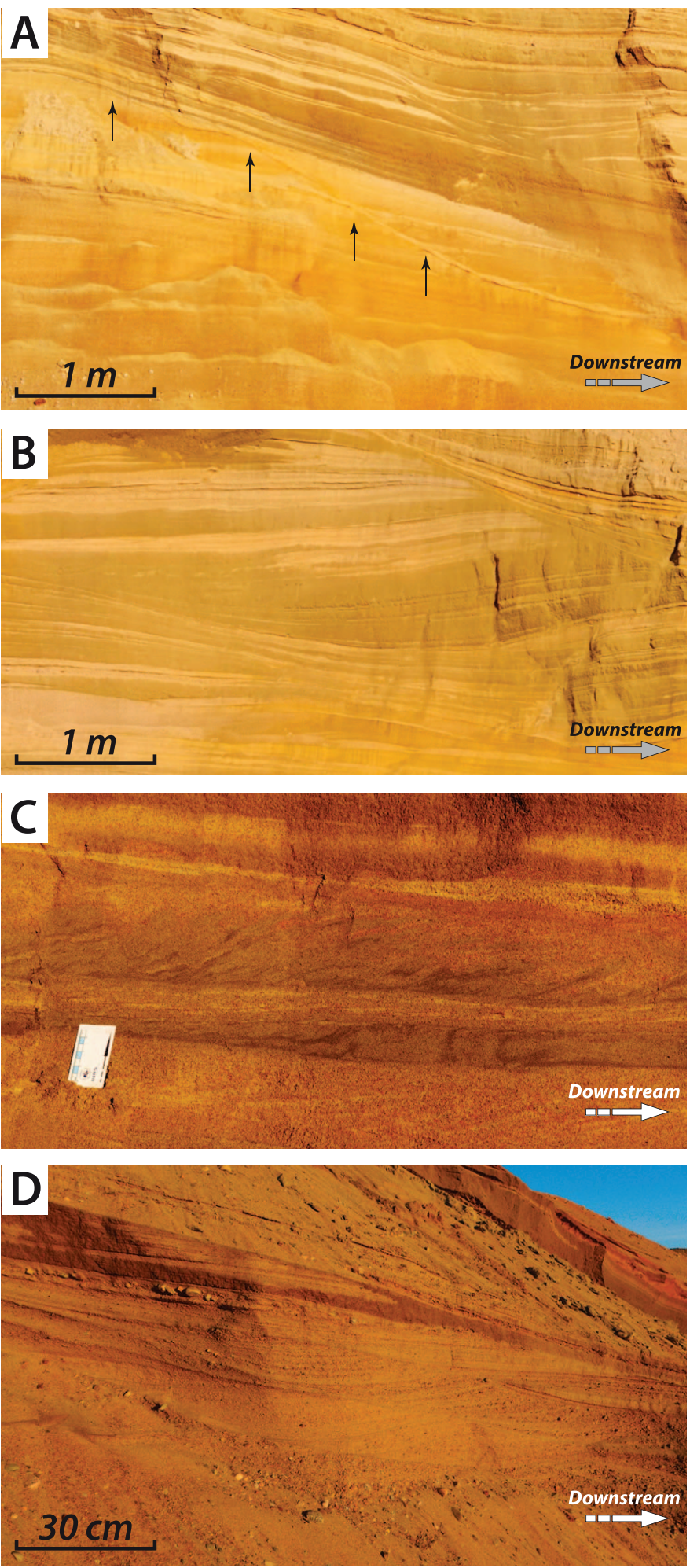

FIG. 6.-Depositional facies in cyclic-step deposits. The paleoflow is to the right. A) A downslope-dipping pseudo-foreset (black arrows), sharply truncating underlying strata and on which backstepping strata onlap. B) Second-order climbing cross strata (antidune deposits). C) Flame structures showing a top-to-the-south shear. D) Pebbly sandy antidune cross-strata in the upper foresets. (humpback dunes, e.g., Fielding 2006). The development of the storm berm over the topsets records a fluvioglacial sediment cutoff, at least at the local scale.

According to their stratigraphic positions (Fig. 3), the backstepping crossstrata were formed in a delta-front setting. The most landward and topographically highest of them are truncated by the lower bounding surface of the topsets pointing to the depth of the delta brink (Figs. 2, 3). Basinward, the lowest of the observed backstepping cross-strata was emplaced at a depth of $>15 \mathrm{~m}$. Similarly, upslope-dipping, undulating beds (Figs. 2, 5, 6D) were emplaced at a depth in the $0-5 \mathrm{~m}$ range. The uncertainty about these estimates is in the order of the tidal range. The occurrence of a conformable relationship between topset and foreset deposits (Fig. 2) implies that this contact is not an unconformity, but only a diastem. No greater depth can be inferred from the overall depositional setting.

\section{A Cyclic-Step Interpretation for the Backstepping Cross-Strata}

Patterns of stratification in backstepping cross-strata resulted from the progressive aggradation of depositional bedforms. A southward sense of flow as indicated by the mean dips of foreset geometries and the overall geomorphic setting indicates that stoss sides were essentially preserved while erosion prevailed along lee sides. Bedform amplitudes are in the 1-3 m range. Wavelengths are reflected by the horizontal spacing of the pseudo-foresets (10-20 m). Individual bedforms (first-order) and superimposed convex-up geometries (second-order) have climbed upslope, and the dip of the pseudo-foresets corresponds to the angle of climb of the aggrading bedforms.

Coarse-grained backstepping strata are interpreted as the result of netdepositional Froude-supercritical flows. In such conditions, laminae geometries correspond to the morphologies of the formative bedforms. Quasi-permanent bedforms that migrate upstream in an orderly train as shown by regularly spaced pseudo-foresets point to either cyclic-step or stable antidune flow conditions (Cartigny et al. 2011, 2014; Postma et al. 2014). Occurrences of second-order, shorter-wavelength bedforms superimposed onto first-order larger-wavelength bedforms indicate that second-order and first-order bedforms correspond to antidunes and cyclic steps, respectively (Spinewine et al. 2009; Cartigny et al. 2014). Scour-dominated cross-stratal patterns in exposures not parallel to the paleoflow suggest curvilinear bedform crests, reminiscent of crescentic, upslope-migrating bedforms highlighted in a number of delta slopes or turbiditic canyons (e.g., Smith et al. 2005, 2007; Hughes Clarke et al. 2014; Normandeau et al. 2014; Turmel et al. 2015).

Erosion associated with successive hydraulic jumps (Parker 1996; Kostic et al. 2010; Cartigny et al. 2014) resulted in the steep erosional surfaces that were referred to in the above description as pseudo-foresets. The hydraulic jumps were positioned on the lee sides and not in the troughs of the bedforms, permitting onlapping contacts of the depositional structures onto the jumprelated pseudo-foresets.

Massive to graded beds similar to top-cut-out turbidites and faintly laminated to diffusely layered sands relate to repeated hydraulic-jump processes (Russell and Arnott 2003; Postma et al. 2009; Lang and Winsemann 2013). Such bed-scale features correspond to sedimentary structures typically described in cyclic steps with stratified flow patterns including a supercritical basal layer (Postma et al. 2014; Postma and Cartigny 2014). A hydraulic jump permits deposition of massive to pebbly sand as well as sand intraclasts (Russell and Knudsen 1999; Carling 2013) in the troughs of the bedforms. Soft-sediment deformation such as sheared flame structures resulted from pressure fluctuations under the unsteady flow (Postma et al. 2009, 2014). Variable near-bed flow conditions occurred along successive lee (mainly erosional) and stoss (depositional, reaccelerating from subcritical to supercritical) sides of the first-order cyclic-step bedforms (Kostic et al. 2010; Cartigny et al. 2014) conferring to the overall flow a transcritical state. Flow reacceleration up to renewed supercritical conditions approaching the following downslope bedform crest resulted locally in the formation of second-order antidunes (Figs. $5,6 \mathrm{~B}$ ). As cyclic steps are known to scale to flow thickness (Spinewine et al 


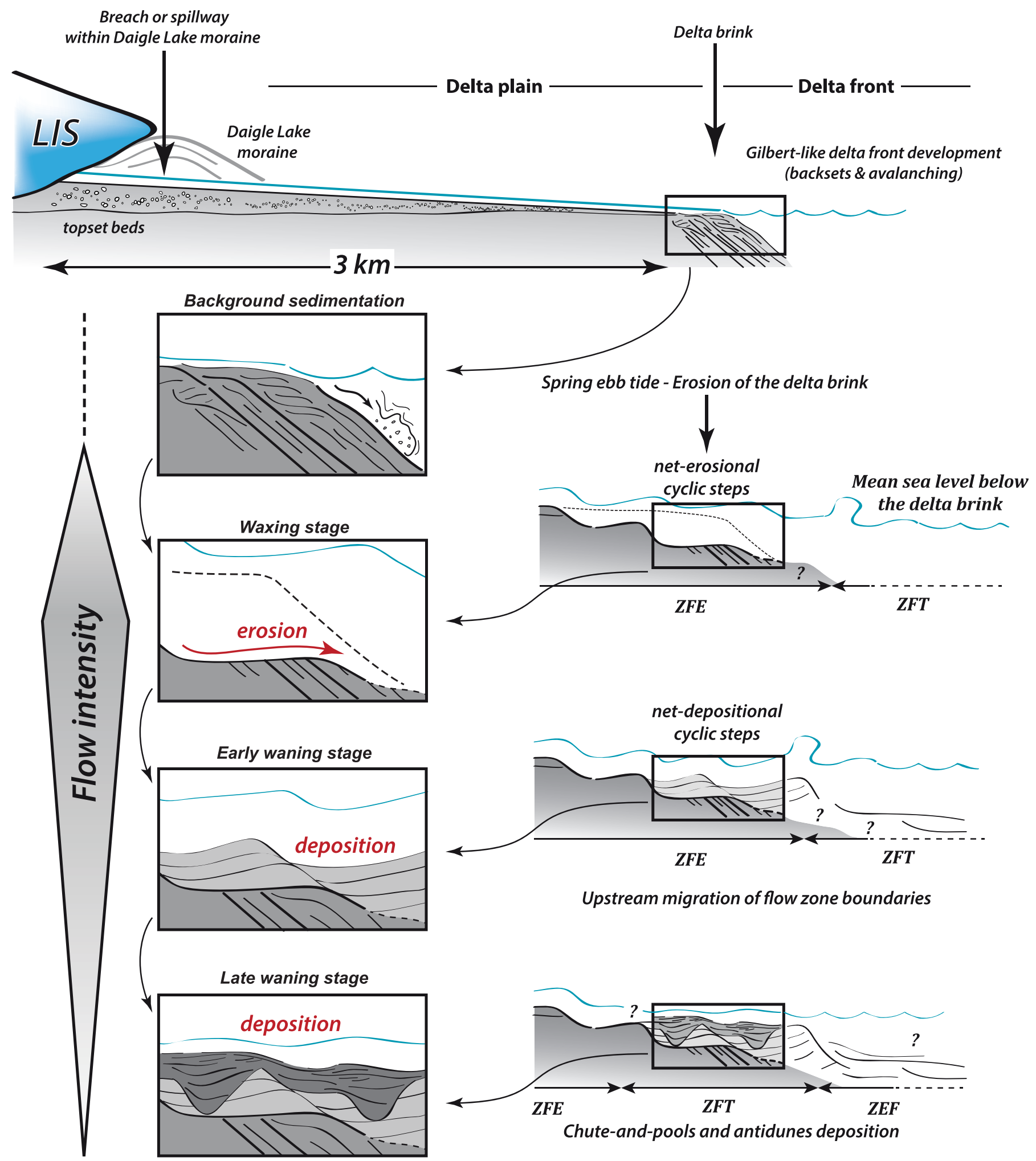

FIG. 7.-Depositional model for river-derived cyclic steps in a delta-front setting beyond the margin of the Laurentide Ice Sheet. ZFE, Zone of Flow Establishment; ZFT, Zone of flow Transition; ZEF, Zone of Established Flow (Russell and Arnott 2003). 


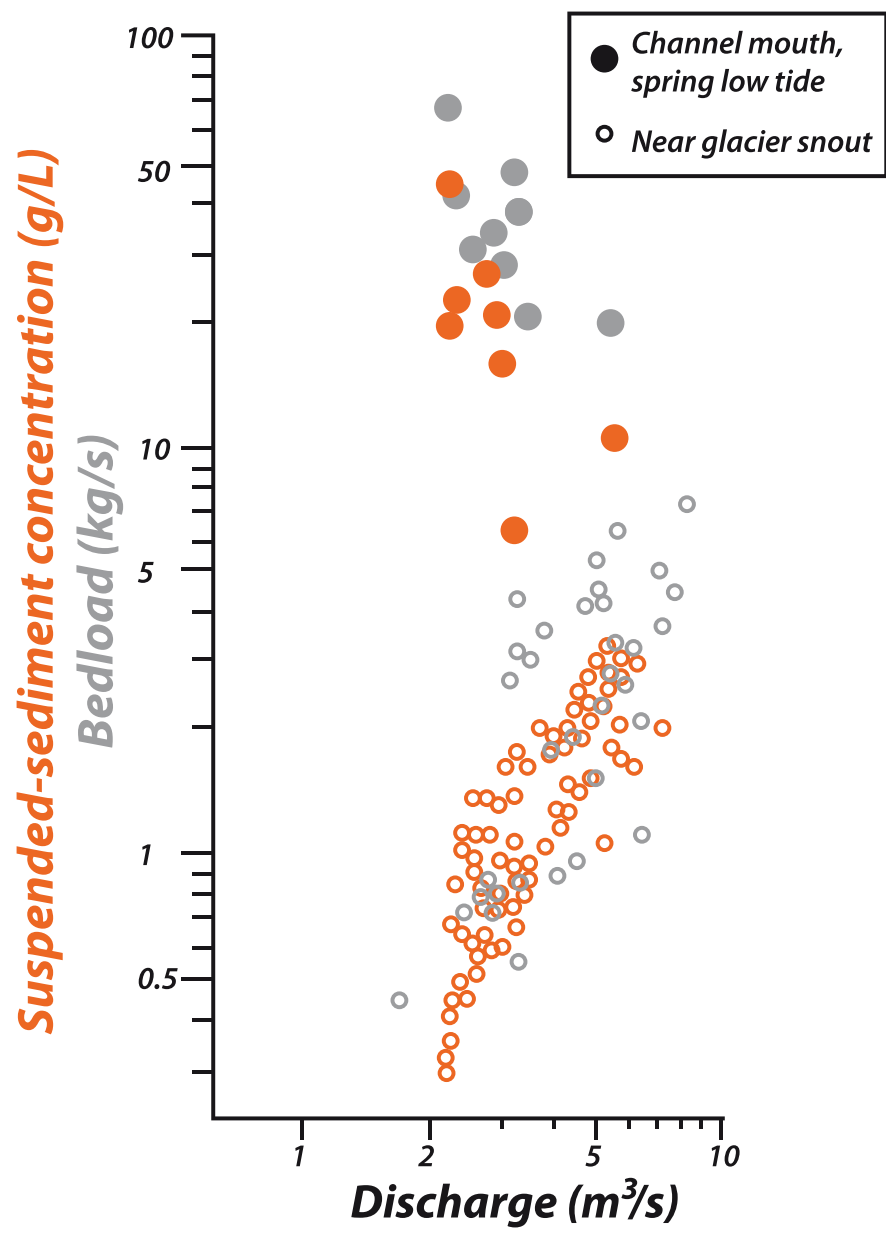

FIG. 8.- Increase in sediment yield in a proglacial river due to tidal drawdown processes. Modified from Smith et al. (1990).

2009; Kostic 2011), bedform wavelengths in the 10-20 m range suggest that the thickness of the transcritical flow was on the order of 1-2 $\mathrm{m}$. This is also in agreement with second-order antidune wavelengths $(<6 \mathrm{~m})$ that suggest a one-meter-thick flow (Normark et al. 1980; Prior and Bornhold 1990; Spinewine et al. 2009).

Backstepping cross-strata originating from cyclic steps are truncated and overlain by the narrow and deep scour in the middle part of the exposure (Fig. 5). Its geometry and its infill including backsets suggest a chute-andpool structure (Russell and Arnott 2003; Russell et al. 2009; Cartigny et al. 2014). Downstepping faults along its landward flank suggest minor gravitational slides in the lee side of the chute-and-pool structure. The subsequent fluidization of larger sand collapses may explain some of the structureless sand layers contributing to the basal scour infill (Fig. 5, see also Turmel et al. 2012; Cartigny et al. 2014, their fig. 15). Well-laminated upslope-climbing tangential cross strata in the upper part of the exposure (Figs. 5, 6D) are ascribed to deposition under supercritical flow conditions characterized by the development of stable antidune bedforms (Cartigny et al. 2011).

The facies sequence including, from the base to the top, cyclic-steps, chuteand-pools, and antidune deposits follows an episode of initial erosion generating the host channel (net-erosional supercritical flows? see Fildani et al. 2013). This corresponds to a depositional context implying temporally and/or spatially decelerating flows. In the proglacial deltaic setting, such a scenario may relate to waning flow conditions, progressive in-channel aggradation driving overflows and expanding flow conditions, or flow interactions with diurnal tides (Smith et al. 1990).

\section{Flood-stage, Background, and Intermediate Flow Conditions}

As interpreted above, foresets with backstepping cross-strata relate to Froude-supercritical flow conditions. In contrast, well-stratified, fine- to medium-grained foreset deposits characterized by ripples, bioturbation, and concentrations of heavy minerals represent background sedimentation and intervening remobilizations along the upper foresets. A combination of marine processes such as waves, tides, and storms resulted in slopes gentler than those of typical Gilbert deltas (Gerber et al. 2008; Fernandez et al. 2011). Muds are virtually absent, indicating that they were exported farther offshore. Unconformable contacts truncating steep foresets (Fig. 3) may represent wave-ravinement surfaces developed after distributary-channel abandonment or migration, or during intervening periods between events of deposition by supercritical bedforms.

Coarse-grained backsets in V-shaped scours depart from structures of background sedimentation stages. Such backsets are frequently recognized in the upper foreset of high-energy Gilbert-type deltas (e.g., Massari 1996). Muto et al. (2012) argued that backsets reflect the development of fluvial cyclic steps on the delta plain and a hydraulic jump in mouth environments. Subcritical flow conditions thus developed downslope along the foresets, and the pseudo-cyclicity observed in backset cross-strata (Fig. 4B) is the consequence of repeated upstream migrations of the fluvial bedform crests and associated hydraulic-jump location. Here, coarse-grained backsets are regarded as the result of intermediate-discharge regimes. A very similar lithology (i.e., coarsegrained pebbly sand) composes the cyclic steps and backsets in V-shaped scours. It is in support of the idea that cyclic steps and backset cross-strata in this case study relate to a common hydraulic regime, the one producing backsets being only less energetic than the one related to cyclic steps (e.g., Gerber et al. 2008).

\section{DISCUSSION}

\section{Cyclic Steps from Supercritical River-Derived Outflows?}

In delta-front settings, supercritical high-density turbidity currents and related upstream migrating bedforms are usually interpreted as initiated by the collapse of oversteepened mouth bars (Hughes Clarke et al. 2012, 2014). This inception process is preferred to other processes tied to river-derived underflows (e.g., hyperpycnite deposits: Plink-Björklund and Steel 2004; Ponce and Carmona 2011) since the latter are generally considered to have too low sediment-carrying potential for generating relatively thick coarsegrained deposits (Talling 2014). In our case study, however, we argue that the mass-wasting hypothesis for generation of cyclic steps is unlikely, thus favoring the river-derived origin.

Indeed, the well-organized stratal pattern in cyclic-step to antidune deposits (Fig. 5) indicates relatively steady and uniform flow patterns. Also, there is no place either for an headscarp large enough to transform in the volume of observed accreted sands (e.g., Prior et al. 1981) or for a flow transformation that would have instantaneously evolved from a gravitational collapse to netdepositional cyclic steps (e.g., Ponce and Carmona 2011) because the cyclic steps are preserved up to the uppermost level of the foresets immediately beneath topsets beds. In addition, the bulk of the cyclic step related deposits contains far fewer coarse particles and is sandier than the topsets beds, the latter thus not being the source of the former.

In as much as cross-strata formed by cyclic steps were specifically emplaced within channels incised through the upper delta front, it can be inferred that supercritical flows were inherited from, or at least tied to, flow conditions characterizing the proglacial delta plain (e.g., Duller et al. 2008). This interpretation would conform to the observation of backsets in V-shaped scours, which can be understood as an indication of cyclic-step flow conditions on the delta plain (Muto et al. 2012). The lack of any patent record of supercritical flow conditions within the delta plain-with the possible exception of humpback dunes - suggests that related bedforms may have been net-erosional. Bedforms may also have formed and been reworked during subsequent background sedimentation stages. However, flow constriction transforming subcritical flows 


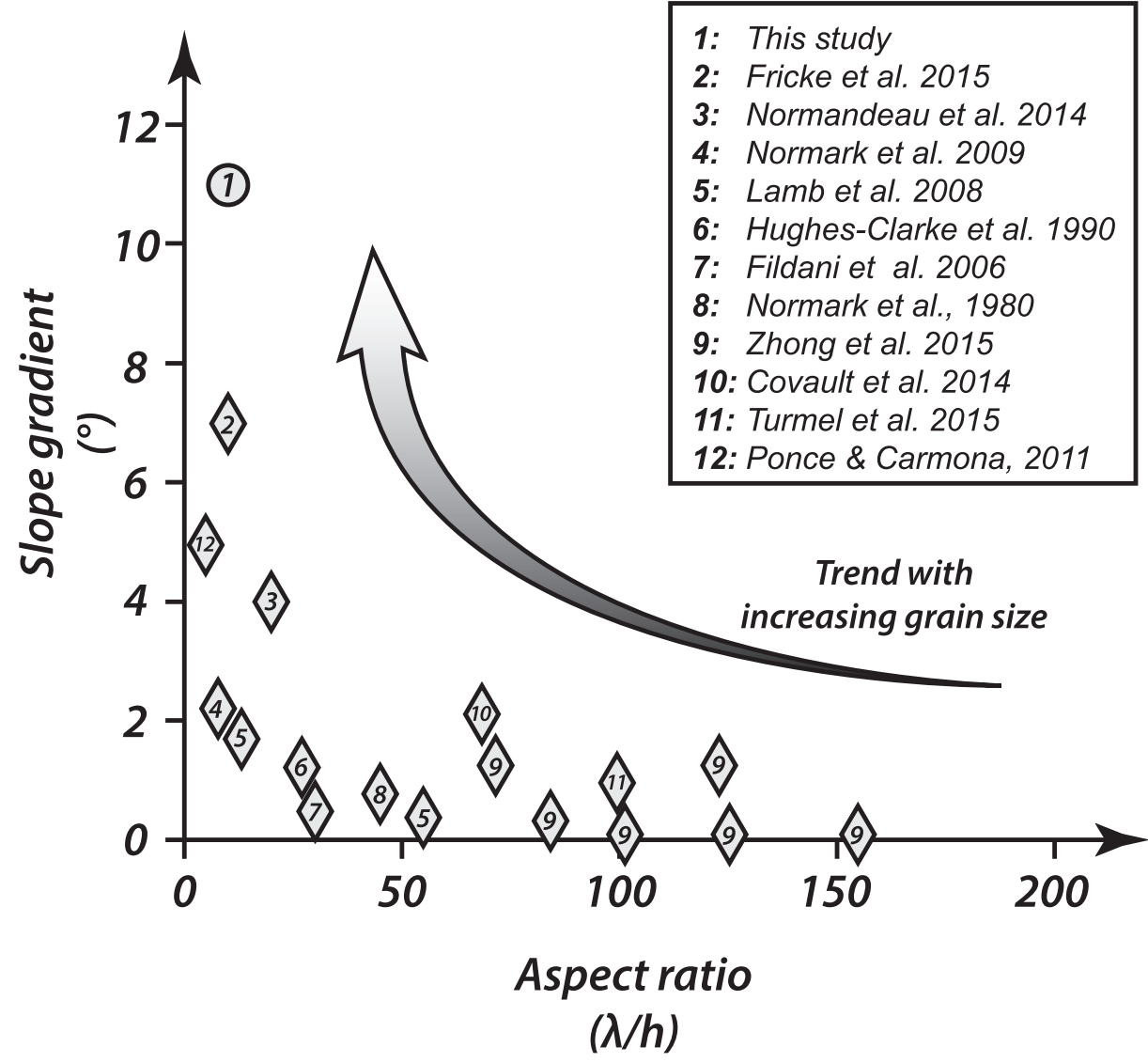

FIG. 9.-Relationships between a dimensionless aspect ratio (wavelength/height) and the depositional slope for some of the cyclic steps documented in the literature. The Sept-Iles case study (circle) is representative of a coarse-grained, steep-slope end member. from the delta plain into supercritical flows in delta-front channels cannot be excluded.

This in-channel configuration confined high-energy flows, which were thus poorly affected by dispersive energy loss in the mouth environment (in contrast of the model of Bates 1953). Such channels are scaled to the upstream distributary channels of the delta plain, in terms of both size and hydraulic regime. A genetic link is then argued between a primary sediment-laden supercritical flow on the delta plain that plunges down and evolves into an underflow that generates the cyclic steps on the upper foresets, a configuration suggested by Spinewine et al. (2009) and Muto et al. (2012). Owing to sufficient density and velocity, buoyancy and friction effects were overcome by the sediment-laden river-derived outflow, which transformed into an underflow (Mutti et al. 2003; Piper and Normark 2009; Turmel et al. 2015).

Flood conditions similar to those that are here inferred are illustrated today at some Icelandic sandur mouths. Here, a riverine flow is frequently observed entering the seawater with surface waves at tens to hundreds of meters off the shoreline in full continuity with those of the river. Then they rapidly narrow seaward, disappearing abruptly (see fig. 3 in Mulder et al. 2003 and fig. 14B in Hine and Boothroyd 1978).

\section{The Role of Tides on Development of Cyclic Steps}

The relative scarcity of cyclic-step cross-strata in the bulk of delta-front deposits suggests that only exceptional, low-frequency flow conditions have generated cyclic steps. We suspect that they most likely necessitated the conjunction of flood conditions (outburst, freshet) on the delta plain and their amplification by ebb-tide processes. In particular, tidal drawdown processes can explain the inception of channel downcutting at the delta brink (Smith et al. 1990). Channels were likely enlarged and rapidly overdeepened, partly owing to supercritical flow conditions derived from the delta plain. The channels thus connected the delta plain and the upper foresets by establishing a new depositional profile (Fig. 7) characterized by largely lower slopes (11-12 ${ }^{\circ}$ ) than that of the background Gilbert-type delta (Gerber et al. 2008; Turmel et al. 2015).

Also, tidal drawdown potentially allows both the suspended-sediment concentration (SSC) and the bedload of the proglacial river outflow to increase by one to two orders of magnitude (up to 50 g.. $\mathrm{L}^{-1}$ according to Smith et al. 1990) (Fig. 8). The sustained river-derived flow can thus plunge down along the delta foresets (Mulder et al. 2003), considering in addition that the estuarine water body of the St. Lawrence was at that time largely diluted by massive meltwater inputs.

Cyclic-step bedforms can be regarded as deposits characterizing a tide-influenced zone of flow establishment (ZFE) of a submerged plane-wall jet with jump (Fig. 7). Here, depositional processes relate to the conduit flow conditions (Russell and Arnott 2003) that characterize the portion of the chute channel located upstream of a main hydraulic jump lying farther downslope (e.g., Mutti et al. 2003). A complex facies suite of subcritical, turbiditic facies is expected to have been deposited farther downslope in the zone of established flow (ZEF) beyond the main hydraulic jump, depending on the residual sediment concentration, pattern of the river flow and the tidal hydrograph, and the gradient distribution along the foresets and in the channel. Afterwards, during the waning stage at low tide, the zone of transition flow is thought to have progressively migrated upstream as evidenced by the occurrences of chutesand-pools and finally antidunes above the cyclic-step bedforms (Fig. 7; see also Lang and Winsemann 2013).

\section{The Role of Slope on Development of Cyclic Steps}

The aspect ratio (wavelength/crest height) of the cyclic steps was close to 10 (Fig. 9), a small ratio in comparison with that of cyclic steps developed in other coarse-grained sand in particular (e.g., Postma et al. 2014) and all other finer- 
grained cyclic steps (e.g., Zhong et al. 2015). The restricted crest spacing may relate to the steep mean slope of the depositional surface $\left(11^{\circ}\right)$, considering that the wavelength of cyclic steps depends in part on the distance that the flow needs to become critical again after the hydraulic jump (Postma and Cartigny 2014).

We plotted the aspect ratio of a panel of cyclic steps found in the literature against the slope along which they develop (Fig. 9). A well-defined decreasing pattern is observed, suggesting that the higher the slope, the lower the aspect ratio. For the steeper slopes, transcritical flows cannot occur, being replaced by permanently supercritical flows (downstream-pulling of the flow by gravity: Kostic 2011; Zhong et al. 2015). In our case study, the slope of the channel incising the delta brink most likely approached the steepest setting in which cyclic steps can develop. In this view, the initial erosion of the delta brink by tidal drawdown, which reduced the initial delta-front slope, may have been a necessary condition in order to promote the development of transcritical flows, the formation of cyclic steps, and the deposition of backstepping cross-strata.

Further, considering that cyclic steps with the lower aspect ratio are generally developed in coarser material (sand and gravel), it seems that development and stability of cyclic steps over steep slopes is associated with coarse material. We thus document a case study where the relationship between the aspect ratio and the slope represents an end member in the field of the supercritical bedforms, at the opposite of long-wavelength, finer-grained cyclic steps deposited over largely less steep channel thalwegs (Zhong et al. 2015).

\section{Implications for Supercritical River-Derived Outflows}

Bedload-dominated, sustained, river-derived flows can be reasonably inferred, at least occasionally, from the overall ice-marginal depositional setting (Marren 2005; Duller et al. 2008). Such conditions may be encountered in a variety of high-energy settings, including glacial outwash and mountainous drainage basins, especially those affected by recurrent rainstorm events and/or if they drain into tide-influenced basins with a significant tidal range (Fielding 2006; Tinterri 2007; Babonneau et al. 2013; Ventra et al. 2015). In this perspective, the cyclic steps and inferred flow conditions documented here may offer a solution for the understanding of the specific circumstances permitting the deposition of thick-bedded, sand-dominated turbiditic successions ascribed to river-derived underflows (Plink-Björklund and Steel 2004; Girard et al. 2012), which are definitely not supported by inferences from modern depositional conditions (Talling 2014).

\section{CONCLUSIONS}

In this study we document coarse-grained (sand and gravel), short-wavelength (10-20 m) cross-strata related to supercritical flow conditions developed in a shallow, fluvioglacial delta front. Both the sedimentary architecture, displaying truncation surfaces against which backstepping strata progressively onlap (pseudo-foresets), and bed-scale depositional facies tied to hydraulic jump processes, attest to cross-strata originating from cyclic steps. The emplacement of cyclic-steps-related cross-strata on upper foresets immediately below the basal topset contact strongly suggests that cyclic steps originate from riverderived, bottom-following underflows (hyperpycnal flows) in a delta-front setting (upper foresets). We suspect that the development of such backstepping cross-strata from hyperpycnal flows was enhanced by tidal drawdown processes. The latter favored the incision of the delta brink and permitted an increase in sediment yield relative to the river outflow, finally driving an inertia-driven underflow and the inception processes for net-depositional cyclic steps.

Our case study differs from most of the other subaqueous published examples by the low aspect ratio $(\sim 10)$ of the bedforms. With kilometer-scale cyclic steps of the deep sea, they represent the two end members of cyclic-steps related cross-stratification recognized in subaqueous slope settings.

\section{ACKNOWLEDGMENTS}

The authors are grateful to David Piper and George Postma for their careful and constructive reviews that significantly contributed to the improvement of the manuscript. Field campaigns were founded by action SYSTER program of the INSU-CNRS (Institut National des Sciences de l'Univers, Centre National de la Recherche Scientifique). This work is a contribution to the "SeqStrat-Ice" ANR project 12-BS06-14.

\section{REFERENCES}

Ayranci, K., Lintern, D.G., Hill, P.R., and Dashtgard, S.E., 2012, Tide-supported gravity flows on the upper delta front, Fraser River delta, Canada: Marine Geology, v. 326-328, p. $166-170$.

Babonneau, N., Delacourt, C., Cancouët, R., Sisavath, E., Bachèlery, P., Mazuel, A., Jorry, S.J., Deschamps, A., Ammann, J., And Villeneuve, N., 2013, Direct sediment transfer from land to deep-sea: insights into shallow multibeam bathymetry at La Réunion Island: Marine Geology, v. 346, p. 47-57.

BAtes, C.C., 1953, Rational theory of delta formation: American Association of Petroleum Geologists, Bulletin, v. 37, p. 2119-2162.

CARLing, P.A., 2013, Freshwater megaflood sedimentation: What can we learn about generic processes?: Earth-Science Reviews, v. 125, p. 87-113.

Cartigny, M.J.B., Postma, G., Van Den Berg, J.H., and Mastbergen, D.R., 2011, A comparative study of sediment waves and cyclic steps based on geometries, internal structures and numerical modeling: Marine Geology, v. 280, p. 40-56.

Cartigny, M.J.B., Eggenhuisen, J.T., Hansen, E.W.M., and Postma, G., 2013, Concentrationdependent flow stratification in experimental high-density turbidity currents and their relevance to turbidite facies models: Journal of Sedimentary Research, v. 83, p. 1046-1064.

Cartigny, M.J.B., Ventra, D., Postma, G., and Van Den Berg, J.H., 2014, Morphodynamics and sedimentary structures of bedforms under supercritical-flow conditions: new insights from flume experiments: Sedimentology, v. 61, p. 712-748.

Covault, J.A., Kostic, S., Paull, C.K., Ryan, H.F., Fildani, A., and Talling, P., 2014, Submarine channel initiation, filling and maintenance from sea-floor geomorphology and morphodynamic modelling of cyclic steps: Sedimentology, v. 61, p. 1031-1054.

DREDGE, L.A., 1983, Surficial Geology of the Sept-Iles Area, Quebec North Shore: Geological Survey of Canada, Memoir 408, $40 \mathrm{p}$.

Duller, R.A., Mountney, N.P., Russell, A.J., AND CAssidy, N.J., 2008, Architectural analysis of a volcaniclastic jökulhlaup deposit, southern Iceland: sedimentary evidence for supercritical flow: Sedimentology, v. 55, p. 939-964.

Fernandez, R.L., Cauchon-Voyer, G., Locat, J., Dai, H.-H., Garcia, M.H., and Parker, G., 2011, Co-evolving delta faces under the condition of a moving sediment source: Journal of Hydraulic Research, v. 49, p. 42-54.

FieLDING, C., 2006, Upper flow regime sheets, lenses and scour fills: extending the range of architectural elements for fluvial sediment bodies: Sedimentary Geology, v. 190, p. 227-240.

Fildani, A., Normark, W.R., Kostic, S., and Parker, G., 2006, Channel formation by flow stripping: large-scale scour features along the Monterey East Channel and their relation to sediment waves: Sedimentology, v. 53, p. 1265-1287.

Fildani, A., Hubbard, S.M., Covault, J.A., Maier, K.L., Romans, B.W., Traer, M., and RowLAND, J.C., 2013, Erosion at inception of deep-sea channels: Marine and Petroleum Geology, V. 41, p. $48-61$.

Gerber, R., Pratson, L.F., Wolinski, L.A., Steel, R., Mohr, J., Swenson, J.B., and Paola, C 2008, Clinoform progradation by turbidity currents: modelling and experiments: Journal of Sedimentary Research, v. 78, p. 220-238.

GILBERT, R., AND CROOKSHANKs, S., 2009, Sediment waves in a modern high-energy glacilacustrine environment: Sedimentology, v. 56, p. 645-659.

GiRARD, F., GHIENNE, J.F., AND RuBinO, J.L., 2012, Occurrence of hyperpycnal flows and hybrid event beds related to glacial outburst events in a Late Ordovician proglacial delta (Murzuq Basin, SW Libya): Journal of Sedimentary Research, v. 82, p. 688-708.

Girard, F., Ghienne, J.F., Du-Bernard, X., and Rubino, J.L., 2015 Sedimentary imprints of former ice-sheet margins: insights from an end-Ordovician archive (SW Libya): EarthScience Reviews, v. 148, p. 259-289.

Fricke, A.T., Sheets, B.A., Nittrouer, C.A., Aluison, M.A., and Ogston, A.S., 2015, An examination of Froude-supercritical flows and cyclic steps on a subaqueous lacustrine delta, Lake Chelan, Washington, U.S.A: Journal of Sedimentary Research, v. 85, p. 754-767.

HILL, P.R., 2012, Changes in submarine channel morphology and slope sedimentation patterns from repeat multibeam surveys in the Fraser River delta, western Canada, in Li, M. C., Sherwood, and P., Hill, eds., Sediments, Morphology and Sedimentary Processes on Continental Shelves: International Association of Sedimentologists, Special Publication 44, p. 47-70.

Hine, A.C., AND Boothroyd, J.C., 1978, Morphology, processes, and recent sedimentary history of a glacial-outwash plain shoreline, Southern Iceland: Journal of Sedimentary Petrology, v. 48, p. 901-920.

Hughes Clarke, J.E., Shor, A.N., Piper, D.J.W., and MaYer, L.A., 1990, Large-scale currentinduced erosion and deposition in the path of the 1929 Grand Banks turbidity current: Sedimentology, v. 37, p. 613-629.

Hughes Clarke, J.E., Brucker, S., Muggah, J., Hamilton, T., Cartwright, D., Church, I., and Kuus, P., 2012, Temporal progression and spatial extent of mass wasting events on the Squamish prodelta slope, in Eberhardt, E., C., Froese, K., Turner, and S., Leroueil, eds., Landslides and Engineered Slopes: Protecting Society through Improved Understanding: London, Taylor and Francis Group, p. 1091-1096. 
Hughes Clarke, J.E., Vidiera Marques, C.R., and Pratomo, D., 2014, Chapter 22: Imaging Active Mass-Wasting and Sediment Flows on a Fjord Delta, Squamish, British Columbia in Krastel, S., J.H., Behrmann, D., Völker, M., Stipp, C., Berndt, R., Urgeles, J., Chaytor, K., Huhn, M., Strasser, and K., Bonnevie Harbitz, eds., Submarine Mass Movements and Their Consequences: Berlin, Springer, Advances in Natural and Technological Hazards Research, p. 249-260

Kostic, S., Sequeiros, O.E. Spinewine, B., and Parker, G., 2010, Cyclic steps: a phenomenon of supercritical shallow flow from the high mountains to the bottom of the ocean: Journal of Hydro-Environment Research, v. 3, p. 167-172.

Kostic, S., 2011, Modeling of submarine cyclic steps: control on their formation, migration and architecture: Geosphere, v. 7, p. 294-304.

LaJeunESSE, P., AND St-ONGE, G., 2013, Late-Wisconsinan submarine moraines along the north shore of the Estuary and Gulf of St. Lawrence (Eastern Canada) [abstract]: Vienna, Austria, European Geosciences Union, General Assembly.

Lamb, M.P., Parsons, J.D., Mullenbach, B.L., Finlayson, D.P., Orange, D.L., and Nittrouer, C.A., 2008, Evidence for superelevation, channel incision, and formation of cyclic steps by turbidity currents in Eel Canyon, California: Geological Society of America, Bulletin, v 120 , p. $463-475$.

LANG, J., AND WinsEMANN, J., 2013, Lateral and vertical facies relationships of bedforms deposited by aggrading supercritical flows: from cyclic steps to humpback dunes: Sedimentary Geology, v. 296, p. 36-54.

Lee, K., McMechan, G.A., Gani, M.R., Bhattacharya, J.P., Zeng, X., and Howell, C.D., 2007, 3-D architecture and sequence stratigraphic evolution of a forced regressive top-truncated mixed-influenced delta, Cretaceous Wall Creek Sandstone, Wyoming, U.S.A: Journal of Sedimentary Research, v. 77, p. 303-323.

LønNe, I., AND NeMEC, W., 2004, High-arctic fan delta recording deglaciation and environment disequilibrium: Sedimentology, v. 51, p. 553-589.

MARREN, P.M., 2005, Magnitude and frequency in proglacial rivers: a geomorphological and sedimentological perspective: Earth-Science Reviews, v. 70, p. 203-251.

MASSARI, F., 1996, Upper-flow-regime stratification types on steep-face, coarse-grained, Gilbert-type progradational wedges (Pleistocene, southern Italy): Journal of Sedimentary Research, v. 66, p. 364-375.

Migeon, S., SAVoye, B., AND FAugèRes, J.-C., 2000, Quaternary development of migrating sediment waves in the Var deep-sea fan: distribution, growth pattern, and implication for levee evolution: Sedimentary Geology, v. 133, p. 265-293.

Mulder, T., AND AleXANDER, J., 2001, The physical character of subaqueous sedimentary density flows and their deposits: Sedimentology, v. 48, p. 269-299.

Mulder, T., Syvitski, J.P.M., Migeon, S., Faugėeses, J.-C., and Savoye, B., 2003, Marine hyperpycnal flows: initiation, behavior and related deposits. A review: Marine and Petroleum Geology, v. 20, p. 861-882

Muto, T., Yamagishi, C., Sekiguchi, T., Yokokawa, M., and Parker, G., 2012, The hydraulic autogenesis of distinct cyclicity in delta foreset bedding: flume experiments: Journal of Sedimentary Research, v. 82 , p. $545-558$.

Mutti, E., Tinterri, R., Benevelli, G., Di Biase, D., and Cavanna, G., 2003, Deltaic, mixed and turbidite sedimentation of ancient foreland basins: Marine and Petroleum Geology, v. 20 , p. $733-755$.

Normandeau, A., Lajeunesse, P., St-Onge, G., Bourgault, D., Drouin, S.S.-O., Sennevilie, S., AND BÉLANGER, S., 2014, Morphodynamics in sediment-starved inner-shelf submarine canyons (Lower St. Lawrence Estuary, Eastern Canada): Marine Geology, v. 357, p. 243-255.

Normandeau, A., Lajeunesse, P., and St-Onge, G., 2015 Morphology and recent sediment dynamics of inner-shelf submarine canyons and channels in a formerly glaciated margin (Lower St. Lawrence Estuary, Eastern Canada), Geomorphology, v. 241, p. 1-18

Normark, W.R., Hess, G.R., Stow, D.A.V., and Bowen, A.J., 1980, Sediment waves on the Monterey Fan levee: a preliminary physical interpretation: Marine Geology, v. 37, p. 1-18

Normark, W.R., Paull, C.K., Caress, D.W., Ussler, W., III., and Sliter, R., 2009, Fine-scale relief related to Late Holocene channel shifting within the floor of the upper Redondo Fan, offshore Southern California: Sedimentology, v. 56, p. 1690-1704.

Occhietti, S., Parent, M., Lajeunesse, P., Robert, F., and Govare, É., 2011, Late PleistoceneEarly Holocene decay of the Laurentide Ice Sheet in Québec-Labrador, in Ehlers, J., P.L., Gibbard, P.D., Hughes, eds., Quaternary Glaciations: Extent and Chronology: Amsterdam, Elsevier, Developments in Quaternary Science, v. 15, p. 601-630.

Orford, J.D., CARTER, R.W.G., AND JENNINGS, S.C., 1991, Coarse clastic barrier environments: evolution and implications for Quaternary sea level interpretation: Quaternary International, v. 9 , p. $87-104$.

Parker, G., 1996, Some speculations on the relation between channel morphology and channel-scale flow structures, in Ashworth, P.J., S.J., Bennett, J.L., Best, and S.J., McLelland, eds., Coherent Flow Structures in Open Channels: New York, John Wiley and Sons, p. 429-432.

Paull, C.K., Caress, D.W., Lundsten, E., Gwiazda, R., Anderson, K., McGann, M., Conrad, J., Edwards, B., AND Sumner, E.J., 2013, Anatomy of the La Jolla Submarine Canyon system: offshore southern California: Marine Geology, v. 335, p. 16-34.

Peltier, W.R., Argus, D.F., and Drummond, R., 2015, Space geodesy constrains ice age terminal deglaciation: the global ICE-6G_C (VM5a) model: Journal of Geophysical Research, Solid Earth, v. 120 , p. $450-487$.

PIPER, D.J.W., AND Normark, W.R., 2009, Processes that initiate turbidity currents and their influence on turbidites: a marine geology perspective: Journal of Sedimentary Research, $\mathrm{v}$. 79, p. $347-362$.

PIPer, D.J.W., Mosher, D.C., AND Newton, S., 2002, Ice-margin seismic stratigraphy of the central Scotian Slope, eastern Canada: Geological Survey of Canada, Current Research 2002-E16.
Plink-BJöRkLund, P., And Steel, R.J., 2004, Initiation of turbidity currents: outcrop evidence for Eocene hyperpycnal flow turbidites: Sedimentary Geology, v. 165, p. 29-52.

Ponce, J.J., and CARmona, N., 2011, Coarse-grained sediment waves in hyperpycnal clinoform systems, Miocene of the Austral foreland basin, Argentina: Geology, v. 39, p. 763-766.

Postma, G., and CarTigny, M.J.B., 2014, Supercritical and subcritical turbidity currents and their deposits: a synthesis: Geology, v. 42, p. 987-990.

Postma, G., Cartigny, M., and Kleverlaan, K., 2009, Structureless, coarse-tail graded Bouma Ta formed by internal hydraulic jump of the turbidity current?: Sedimentary Geology, v. 219, p. 1-6.

Postma, G., Kleverlaan, K., Cartigny, M.J.B., And Mohrig, D., 2014, Recognition of cyclic steps in sandy and gravelly turbidite sequences, and consequences for the Bouma facies model: Sedimentology, v. 61, p. 2268-2290.

Prior, D.B., AND BorNHOLd, B.D., 1989, Submarine sedimentation on a developing Holocene fan delta: Sedimentology, v. 36, p. 1053-1076

Prior, D.B., AND Bornhold, B.D., 1990, The underwater development of Holocene fan deltas in Colella, A., and D.B., Prior, eds., Coarse-Grained Deltas: International Association of Sedimentologist, Special Publication 10, p. 75-90.

Prior, D.B., Wiseman, W.J., AND Bryant, W.R., 1981, Submarine (landslide) chutes on the slopes of fjord deltas: Nature, v. 290, p. 326-328.

Russell, A.J., AND ARNOTT, R.W.C., 2003, Hydraulic-jump and hyperconcentrated-flow deposits of a glacigenic subaqueous fan: Oak Ridges Moraine, Southern Ontario, Canada: Journal of Sedimentary Research, v. 73, p. 887-905.

Russell, A.J., AND KNudsen, O., 1999, An ice-contact rhythmite (turbidite) succession deposited during the November 1996 catastrophic outburst flood (jokulhlaup), Skeidararjokull, Iceland: Sedimentary Geology, v. 12, p. 1-10.

Russell, H., Sharpe, D., AND BAJC, A., 2009, Sedimentary signatures of the Waterloo Moraine, Ontario, Canada, in Hambrey, M.J., P., Christoffersen, N.F., Glasser, and B., Hubbard, eds. Glacial Processes and Products: International Association of Sedimentologists, Special Publication 39 , p. 85-108.

Sequeiros, O.E., Spinewine, B., Garcia, M.H., Beaubouef, R.T., Sun, T., and Parker, G., 2009 Experiments on wedge-shaped deep sea sedimentary deposits in minibasins and/or on channel levees emplaced by turbidity currents. Part I. Documentation of the flow: Journal of Sedimentary Research, v. 79, p. 593-607.

Shaw, J., Gareau, P., and Courtney, R.C., 2002, Palaeogeography of Atlantic Canada 13-0 kyr: Quaternary Science Reviews, v. 21, p. 1861-1878.

Smith, D.P., Ruiz, G., Kvitek, R., And Iampietro, P.J., 2005, Semiannual patterns of erosion and deposition in upper Monterey Canyon from serial multibeam bathymetry: Geological Society of America, Bulletin, v. 117, p. 1123-1133

Smith, D.P., Kvitek, R., Iampietro, P.J., and Wong, K., 2007, Twenty-nine months of geomorphic change in upper Monterey Canyon (2002-2005): Marine Geology, v. 236, p. 79-94

Smith, N.D., Phillips, A.C., AND Powell, R.D., 1990, Tidal drawdown: a mechanism for producing cyclic sediment laminations in glaciomarine deltas: Geology, v. 18, p. 10-13.

Spinewine, B., Sequeiros, O.E., Garcia, M.H., Beaubouef, R.T., Sun, T., Savoye, B., and Par KER, G., 2009, Experiments on wedge-shaped deep sea sedimentary deposits in minibasins and/or on channel levees emplaced by turbidity currents. Part II. Morphodynamic evolution of the wedge and of the associated bedforms: Journal of Sedimentary Research, v. 79, p 608-628.

Syvitski, J.P., AND Farrow, G.E., 1983, Structures and processes in bayhead deltas: Knight and Bute Inlet, British Columbia: Sedimentary Geology, v. 36, p. 217-244.

TAlling, P.J., 2014, On the triggers, resulting flow types and frequencies of subaqueous sediment density flows in different settings: Marine Geology, v. 352, p. 155-182.

TinTERri, R., 2007, The Lower Eocene Roda sandstone (south-central Pyrenees): an example of a flood-dominated river-delta system in a tectonically controlled basin: Rivista Italiana di Paleontologia e Stratigraphia, v. 113, p. 223-255.

Turmel, D., Locat, J., Cauchon-Voyer, G., Lavoie, C., Simpkin, P., Parker, G., and Lauzière, P., 2010, Morphodynamic and slope instabilities observations at Wabush Lake, Labrador, in Mosher, D.C., ed., Submarine Mass Movements and Their Consequences: Berlin, Springer, Advances in Natural and Technological Hazards Research, p. 435-446.

TuRmel, D., LoCAT, J., AND PARKER, G., 2012, Upstream migration of knickpoints: geotechnica considerations, in Yamada, Y., K., Kawamura, K., Ikehara, Y., Ogawa, R., Urgeles, D. Mosher, J., Chaytor, and M., Strasser, eds., Submarine Mass Movements and Their Consequences: Springer, Amsterdam, Advances in Natural and Technological Hazards Research, p. $123-132$.

Turmel, D., Locat, J., AND Parker, G., 2015, Morphological evolution of a well-constrained, subaerial-subaqueous source to sink system: Wabush Lake: Sedimentology, v. 62, p $1636-1664$.

Ventra, D., Cartigny, M.J.B., Bijkerk, J.F., and Acikalin, S., 2015 Supercritical-flow structures on a Late Carboniferous delta front: sedimentological and paleoclimatic significance: Geology, v. 43, p. 731-734

Wright, L.D., AND FrIEDRICHS, C.T., 2006, Gravity-driven sediment transport on continental shelves: a status report: Continental Shelf Research, v. 26, p. 2092-2107.

Zhong, G., Cartigny, M.J.B., Kuang, Z., and Wang, L., 2015, Cyclic steps along the South Taiwan Shoal and West Penghu submarine canyons on the northeastern continental slope of the South China Sea: Geological Society of America, Bulletin, v. 127, p. 804-824.

Received 14 April 2015; accepted 30 October 2015. 